\title{
WEST, Paige. 2006. Conservation is our government now: the politics of ecology in Papua New Guinea. Durham and London: Duke University Press.
}

Guilherme F. W. Radomsky (PPGAS/UFRGS)

Adicionando mais aportes ao nosso conhecimento sobre a recente e discutida "governamentalidade ambiental", Paige West (2006) realiza uma bela etnografia sobre as políticas de conservação da natureza na Melanésia. Envolvendo-se durante alguns anos entre pequenos agricultores, técnicos de ONGs, turistas e pesquisadores na região de Maimafu, na Papua Nova Guiné, West relata o trabalho antropológico de imersão no intenso debate e na condução da implementação de uma unidade de conservação ambiental, especificamente em Crater Moutain, nos territórios do povo Gimi.

O titulo do livro representa muito bem o ideário que é emprestado ao povo Gimi, habitante da área: o desejo de se desenvolver presente desde os primeiros contatos com os Ocidentais; no entanto, no momento em que o discurso se volta para a sustentabilidade, este desejo é orientado a um tipo de desenvolvimento governado pela conservação do ambiente que circunda as populações e do qual estas retiram seu sustento. Todavia, o complexo da situação é que há pontos de vista distintos acerca de conservação e no que diz respeito ao que seja desenvolvimento: mediadores de ONGs vinculadas aos projetos ambientais enfatizam a importância da defesa da natureza para que os Gimi atinjam o desenvolvimento; os habitantes locais entendem diferentemente tanto o que significa preservar (não relacionam com o ato de "não desmatar", ou seja, nunca existe para eles uma "não relação com o ambiente") quanto o que querem com desenvolvimento: objetos, trocas, dinheiro, relações. $O$ equívoco na tradução entre culturas parece ser tarefa difícil de escapar.

West repensa as relações entre os locais e as entidades que realizam trabalhos na área a partir também de etnografias anteriores, especialmente a de Gillian Gillison, mas tendo referências os trabalhos de grande envergadura sobre a Melanésia. A troca como relação sempre foi um ponto crucial no entendimento do modo de vida das populações da Papua Nova Guiné, desde o clássico de Malinowski que destacou o kula (trocas-dom entre os habitantes das ilhas). A troca é uma das formas principais de relação entre pessoas e grupos assumindo particularidades em caso de dádivas 
“[...] para os Gimi, essa paisagem [do território] foi feita; ela foi produzida por meio das trocas entre as pessoas e o ambiente" (p. 51). Portanto, a categoria de "naturalidade", apreciada entre os modernos, sucumbe nessa relação. E hoje é este ambiente o alvo da proteção das organizações. Assim, West sustenta que o modo de relação que os Gimi procuram na relação com as ONGs fundamenta-se nesse princípio: de que fazendo algo para o projeto de conservação, ganharão algo em troca - e esse "em troca" é justamente o desenvolvimento. Um dos pontos capitais situa-se no fato das entidades acabam promovendo o discurso da perpetuação das trocas, contudo a etnografia relata que o processo nunca ocorre no idioma das populações locais. E não é somente neste caso relatado em Conservation is our government now, pois a questão é saber se populações tradicionais, quando envolvidas no discurso e nas práticas ditas sustentáveis, angariam um tipo de desenvolvimento que acaba se revelando por meio da mercantilização do ambiente em que vivem e do seu modo de viver.

O trabalho de West efetua uma descrição das relações entre os Gimi e as entidades, embora em alguns pontos fuja do argumento principal ao exceder nas descrições cotidianas. Ainda assim, o texto é marcado por uma preocupação, orientada parcialmente pela perspectiva de Michel Foucault, em demonstrar como narrativas e discursos edificam imagens. Estas representações são poderosos instrumentos de controle e vão desde o que seja o Maimafu, no que constitui a exuberância da natureza, o que deve ser priorizado acerca dos "pássaros do paraíso" e sua possível extinção, até a produção efetiva do que são as pessoas locais: são pobres, pouco desenvolvidos, com escassa educação, sedentos por objetos do mundo Ocidental, interessados em ganhar coisas e não trabalhar para obtê-las.

O conjunto de relações complexas oferece uma descrição em que aparecem muitos personagens, atividades e processos não-locais, imagens e representações de entidades externas, bem como a especificidade das interações e praticas próprias do lugar. Na realidade, a antropóloga mostra uma comunidade repleta de relações translocais em que aparece, por exemplo, a produção de café orgânico e a luta dos camponeses para obter certificação para seu comércio internacional. Não há ilusões, turistas e ativistas desapontam-se quando vêem os povos nativos usando roupas de segunda mão: “Eu pensei que seria mais parecido com o que é mostrado nos programas dos canais Discovery Channel ou National Geographic", refere West (p. 166) sobre a opinião de um turista que conheceu a área. Mesmo assim, a etnografia mostra detalhes imperceptíveis à atividade turística, por exemplo, o modo de manejar propriedades, tema sempre candente. “Quando você pergunta a pessoa quem é dono do quê, você não recebe um quadro explicativo fixo; você recebe uma estória de relações" (p. 109). Essa história de relações coloca desafios ao modo como as diferentes gerações entendem a terra e o projeto de conservação: enquanto os mais velhos percebem o território e o ambiente sendo co-produzidos entre a população e a natureza - "antes não havia pessoas dizendo o que nos devíamos fazer" (p. 65) - muitos jovens sentem-se seduzidos pelos aparatos e ideais do mundo que os circunda: "nós queremos ser modernos e desenvolvidos" (p. 65). É de se destacar que muitas das transformações são dadas a partir da chegada das religiões cristãs à ilha.

Assim sendo, a religião é outro assunto polêmico. Com a inserção da igreja adventista do sétimo dia, não 
destes conceitos (sobretudo quando retirados de contextos específicos e exportados para culturais exógenas a eles) mas até mesmo costumes alimentares e rituais foram transformados. Sob o ponto de vista do desenvolvimento o discurso religioso se apresenta muito semelhante ao que a literatura sobre estudos de desenvolvimento mostra: as populações locais são passíveis de transformação porque a elas lhes falta o que o mundo "desenvolvido" possui. Enquanto isto, para os Gimi a noção de desenvolvimento, mesmo que entendida como algo que vem de outro lugar, não passa pelos mesmos mecanismos com que as entidades que não se cansam em tutelá-los advogam.

O que parece ser central na analise de West é sua arguta observação - a partir de uma etnografia vigorosa na região - de que o desenvolvimento dificilmente pode ser levado de um lugar a outro; o desenvolvimento não se reaplica sem que matrizes culturais locais façam uma readequação com base nas construções simbólicas do grupo ou sociedade em questão, inclusive no que diz respeito à desigualdade de gênero, assunto que é abordado do início ao fim do livro. Aquilo que os sujeitos desejam - o caso da participação feminina nos projetos, muitas vezes silenciado - se afronta com o que lhes é apresentado pelos mediadores interessados em assuntos específicos, tais como a preservação dos ninhos de águias e na manutenção da exuberância da floresta - além de que estas implicam mudanças de atividades e a criação de uma categoria como a de sujeitos preocupados com o ambiente. Mais que isso, o papel do mercado no processo parece ser elevado a uma certa naturalidade e os Gimi vêem sua cultura experimentada como algo a ser fragmentada e (possivelmente) traduzida em valor econômico: entidades insistem em que as tradicionais sacolas feitas por mulheres devem ser levadas ao espaço do mercado, sendo isto mais um argumento feito em torno da ideia que dessa forma o desenvolvimento (a benesse econômica) virá.

Ao final, a narrativa neoliberal e a agenda para o desenvolvimento parecem se encontrar numa nova arquitetura, bem distinta de um livre mercado sem qualquer condução ou dirigismo. A liberdade de mercado é produzida e constituída discursivamente enquanto espaço da livre troca, ou seja, esforço de agenciamentos efetivos. Conservation is our government now adiciona detalhes sobre como se atualiza no local este esquema (neo)liberal de governo associado à temática ambiental, embora o assunto merecesse uma melhor análise de como estes processos são, pelo menos em parte, produzidos em outras esferas, em agências nacionais e internacionais de desenvolvimento, organismos multilaterais e ONGs de atuação transnacional. Ainda assim, o trabalho de Paige West é frutífero para se pensar sobre as formas liberais de condução da economia e a nova racionalidade que se projeta sobre o ambiente e as populações que vivem nestes territórios. É especialmente desafiadora a proposta de uma etnografia sobre unidades de conservação que capte as múltiplas vozes, os diferenciais de gênero, os mitos do lugar, os processos de construção do espaço, os esquemas de poder, as redes de entidades, o imaginário dos distintos atores e as ontologias conflitantes sem perder a ligação de todas estas dimensões na discussão sobre um tema multifacetado e elusivo que é o desenvolvimento.

Guilherme F. W. Radomsky é doutorando em Antropologia Social (PPGAS/UFR$G S$ ) e bolsista $C N P q-S W E$ na University of North Carolina at Chapel Hill. 